Journal of Social Sciences (COES\&RJ-JSS)

ISSN (E): 2305-9249 ISSN (P): 2305-9494

Publisher: Centre of Excellence for Scientific \& Research Journalism, COES\&RJ LLC

Online Publication Date: $1^{\text {st }}$ October 2017

Online Issue: Volume 6, Number 4, October 2017

https://doi.org/10.25255/jss.2017.6.4.886.901

\title{
The Impact of Corporate Governance on Auditor Selection: An Empirical Study on Service Companies in Jordan
}

\author{
Nurah Musa Al-Lozi \\ Department of Accounting, School of Business, \\ The University of Jordan
}

Article History:

Received Date: $10^{\text {th }}$ September 2016; Revised Date: $12^{\text {th }}$ October 2016; Acceptance Date: $17^{\text {th }}$ November 2016; Publication Date: 1st October 2017

\begin{abstract}
:
Corporate governance mechanism is of great importance, since it is a key determinant of high (low) quality auditors. This research is intended to examine the impact of corporate governance on auditor selection in several service companies listed in Amman Stock Exchange. To test the research hypotheses, descriptive methods and statistical analyses will be used in this research including the percentages, means, and the standard deviations as well as the binary logical regression.
\end{abstract}

\section{Keywords:}

Corporate Governance, Auditor Selection, Jordan

\section{Citation:}

Nurah, Musa al-Lozi (2017); The impact of corporate governance on auditor selection : an empirical study on service companies in Jordan; Journal of Social Sciences (COES\&RJ-

JSS), Vol.6, No.4, pp:886-901; https://doi.org/10.25255/jss.2017.6.4.886.901. 


\section{Introduction}

In the early 2000s, the enormous bankruptcies (and Fraud) of Enron and WorldCom, as well as lesser corporate scandals, such as Adelphia communication, AOL, Arthur Andersen, Global crossing Tyco, led to a global realization of the importance of independent attestation of corporate financial statements and internal control systems for sound corporate governance (CG). This is reflected in the passage of the Sarbanes-Oxley Act of 2002. Corporate governance mechanism is of great importance, since it is a key determinant of high (low) quality auditors. Good (bad) corporate governance will result in a selection of high (bad) quality auditors who in turn create effective (ineffective) audit monitoring, so that firms can obtain their capital at a lower cost and communicate more efficiently with their stakeholders (Mahdavi, Mahalouie, Ebrahimi and Sarikhani, 2011), (Lin, Z.J and Liu, M., 2009), (Broye and Weill, 2008), (Watts and Zimmerman, 1986).

Also, Good (bad) corporate governance will result in more (less) reliability and confidence in the firm's financial statements, accounting and financial information for shareholders and stakeholders (Gao and Kling, 2012), (Wang and Zhang, 2007), (Patel, Balic and Bawkira, 2002). The agency problem -which is the conflict of interests between the principal and the agent due to the separation of control and ownership-, justifies the need for corporate governance research. Managers (the agents) may undertake actions that are harmful or at least not beneficial to the owners (the principal). Also, managers may pursue their own interests, goals and incentives at the expense of the owners in the absence of symmetric information (Berle and Means, 1933). According to the organization of economic cooperation and development (OECD), corporate governance is one key element in improving economic efficiency, growth and enhancing investor confidence in order to have financial stability. Corporate governance involves the set of rules and practices that govern the relationships between the firm's management and its shareholders and other stakeholders such as suppliers, employees, tax agencies, creditors...etc. Corporate governance also provides the structure through which the objectives of the firm are set and the means of attaining those objectives and monitoring performance are determined (OECD, 2004).

Larcker, Richardson and Tuna (2007) defined corporate governance more generally as "the set of mechanisms that influence the decisions made by managers when there is separation of ownership and control". On the other hand, (Armstrong, Guay and Weber, 2010) viewed corporate governance as "the subset of a firm's contracts that help align the actions and choices of managers with the interests of shareholders". In global economy, corporate governance rules have become of great significance. They reinforce the success of economic and organizational reforms undertaken in the dynamic environment; they enhance confidence and stability in any national economy and investment climate; they assure fairness and transparency to protect investors and indicate the level of management commitment toward good governance, control and accountability. Good corporate governance must provide proper remunerations in the form of incentives and rewards for the board and management to achieve objectives that are in the interest of the firm and its owners, and must facilitate effective monitoring. The presence of effective corporate governance system will create confidence and stability in every individual firm and economy as a whole, so that firms can obtain capital at a lower cost and can use resources more efficiently.

The controls that affect management activities and corporate performance are divided into two groups. First, internal corporate governance controls which are related to the effective 
interaction among the board, management, shareholders and other internal stakeholders. Second, external corporate governance controls which external stakeholders exercise over organization (Brickley, A. and Zimmerman, L., 2010). After discussing corporate governance, its role in the firms and economy as a whole and its controls, it is worthy to shed lights on corporate governance aspects in Jordan. Jordan is a civil law country, in which obligations, responsibilities and rights should be supported by legislation. However, the legal and regulatory framework consists of securities laws, companies' laws, rules and regulations of capital market institutions, banks laws, insurance supervision laws and finally privatization laws. Jordan has recently noticed major concerns in corporate governance (CG) through adopting a set of economic, financial, legislative reforms to enhance transparency, control and accountability. The crisis caused by "Shamayleh Gate" Scandal has reinforced the concerns in consolidating the foundations and the principles of corporate governance in the economy. Corporate governance rules for listed firms at Amman stock exchange (ASE) are based on a set of principles, which are: first, the rights of shareholders, second, the equitable treatment of shareholders, third, disclosure and transparency, fourth, the role of stakeholders in corporate governance, and finally the responsibilities of the board.

\section{Literature Review}

The agency theory, which relates the agency problem (that is the conflict of interests between the principal and the agent) to the separation of control and ownership, justifies the need for corporate governance research (Berle and Means, 1933; Jensen and Meckling 1976). Corporate governance defines the structure, procedures and process of every organization in which business managed and directed. The presence of effective corporate governance mechanism eliminates the conflict of ownership and control by defining the rights, responsibilities and the interests of the principals and agents (Khan, 2011). The selection of auditors indicates the degree of corporate governance, where auditors are one of effective corporate governance tools.

Many studies have been conducted on auditor selection predominantly in the U.S with occasional studies in countries such as Australia and U.K where the auditing environments are relatively similar. The presence of extensive studies relates to developed capital markets in these countries. On the other hand, there are fewer studies in emerging capital market countries. One study (conducted in a less developed Chinese context) investigated the impact of corporate governance on auditor selection; this study used three variables to proxy for firms' internal corporate governance mechanism, i.e., the ownership concentration, the size of the supervisory board (SB), and the duality of CEO and chairman of board of directors (BoDs). The results show that firms with larger controlling shareholders, with smaller size of SB, or in which CEO and BoDs chairman are the same person, are less likely to hire a (high-quality) auditors. This suggests that when benefits from lowering capital raising costs are trivial, firms with weaker internal corporate governance mechanism are inclined to choose low-quality auditors so as to capture and sustain their opaqueness gains. On the other hand, with improvement of corporate governance, firms should be more likely to appoint high-quality auditors (Lin, Z.J and Liu, M., 2009). When they replaced the second variable (which is the size of the board) a year after with another variable (which is the effectiveness of SB), they found that effectiveness of the SB does not have any significant impact on auditor selection (Lin, Z.J and Liu, M., 2010). 
Also, another study (conducted in Iran) investigated the impact of corporate governance on auditor selection; this study used six variables to proxy for firms' corporate governance mechanism, i.e., the institutional ownership, the managerial ownership, the family ownership, the ownership concentration, the board composition and the duality of CEO and chairman roles. The results show that increasing the percentage of outside directors will increase the possibility of choosing high-quality audit firms. The institutional ownership has a negative meaningful relationship with the possibility of choosing high quality audit firms. The board composition has a positive meaningful relationship with the possibility of choosing high quality audit firms for all companies in the sample. The results for other variables were varying because industry type plays the role of a modifying factor for the results (Mahdavi, Mahalouie, Ebrahimi and Sarikhani, 2011).

A relevant study of auditor selection, client firm characteristics and corporate governance finds that client firm size, level of shareholdings by foreign shareholders, and membership in the finance sector are the firm-specific variables that are positively and significantly associated with the selection of High quality auditors versus the other auditors. This finding is consistent with the findings of extant auditor selection literature in both developed markets and in the emerging market of Athens Stock Exchange (Asku, Onder and Saatcioglu, 2007). Another paper investigated the corporate governance, auditor selection and auditor switch; in this paper three variables are used to proxy for firms' internal corporate governance mechanism, i.e., the ownership concentration, the size of the supervisory board (SB), and the duality of the CEO and the chairman of the board of directors (BoDs).the results find that audit quality and switching to a larger auditor have a positive (negative) impact on earnings response coefficients (ERCs) for firms with positive (negative) abnormal earnings. On the other hand, switching to a smaller auditor has a negative (positive) impact on ERCs for firms with positive (negative) abnormal earnings (Ming, 2007). Also a relevant research investigated corporate governance, legal environment and auditor selection, the results show that the positive association between auditor selection and the firm-level governance scores is weaker (stronger) in a low (high) legal environment (Hossain, Lim, and Tan, 2010).

\section{Research Problem}

This research is intended to examine the impact of corporate governance on auditor selection in several service companies in Jordan listed in Amman Stock Exchange. Specifically, this research focuses on the influence of board size, board independence, CEO duality and institutional ownership on auditor selection. One controlling variable is considered in this research: Firm size. The importance of this research can be explained in many points. First, there are few empirical studies that examine auditor selection decisions in the emerging economies; even the auditor selection issue has a critical impact on the credibility of corporate financial reporting and the operation of capital market. Second, this research is intended to examine and evaluate the effect of corporate governance on auditor selection by considering Jordan as a case study. Third, this research is intended to shed lights on the strengths and weaknesses of corporate governance in different capital market environments and can provide meaningful information for harmonization and standardization process all over the world. 


\author{
Construction of Variables and Hypotheses Development \\ Construction of Variables \\ Independent Variables \\ Board Size (BRD_SIZE)
}

literature findings suggest that large boards result in less effective coordination, increased information costs and confused decision-making (Lipton and Lorsch, 1992) and (Jensen, 1993). This variable (BRD_SIZE) is measured by the number of directors sitting on the board of a firm in a particular financial year; it takes the value of 1 if the firm's board size is less than the sample median and 0 otherwise.

\title{
Board Independence (BRD_IND)
}

Independent non-executive directors can monitor and control the actions of opportunistic executive directors resolving agency problem between managers and the owners (Brickley et al. 1994) and (Fama, 1980; Fama and Jensen, 1983).

The measures of this variable (BRD_IND) are:

Proportion of outside directors on the board

CEO tenure (the number of years the CEO has served on the board)

Family affiliation of board of directors

This variable takes the value of 1 if it is above the sample median (Good governance) and 0 otherwise (bad governance).

\section{CEO Duality (DUAL)}

Literature findings suggest that the separation of chief executive officer and chairman roles indicates the effectiveness of the board, i.e. the separation enhances shareholders' monitoring effectiveness over managers' decisions (Yermack, 1996). This variable (DUAL) takes the value of 1 if there is a separation of the chief executive officer and chairman roles in the company and 0 otherwise.

\section{Institutional ownership (INST_OWN)}

Institutional owners have an important influence on the level of CEO and their Remuneration; and on manager's performance and activities directly through their ownership and indirectly by their ability to trade shares (Ozkan, 2006) and (Gillan and Starks, 2002). This Variable (INST_OWN) will be measured by the number of shares owned by institutional owners and the proportion of their ownership in the firm (PIO).

\section{Dependent Variable}

\section{Auditor selection: Big Four Auditors Vs Other Auditors (AUDIT)}

In this study we use a binary classification to divide auditors into two categories: the big four auditors to proxy for high-quality auditors and non-big four auditors to proxy for lowquality ones. The size and reputation of the audit firm is used to measure the quality of the auditor, where the big four auditors are considered to be : Earnest and Young, KPMG, Deloitte and Toche and Coopers. This variable takes the value of 1 if the firm is a big four audit firm (High Quality) and 0 otherwise (Low Quality).

\section{Control Variable}

\section{Firm Size (F_SIZ)}

This variable will be measured by $\log$ of assets. Small firms' selection of auditors is strictly different from large firms (Gao and Kling, 2012). 


\section{Hypotheses Development}

In this study, five research hypotheses are developed and will be tested, as explained below:

H1: there is a positive meaningful relationship between board size and the possibility of selecting high quality auditors.

$\mathrm{H} 2$ : there is a positive meaningful relationship between board independence and the possibility of selecting high quality auditors.

$\mathrm{H} 3$ : there is a positive meaningful relationship between duality of the CEO and chairman roles and the possibility of selecting high quality auditors.

$\mathrm{H} 4$ : there is a positive meaningful relationship between institutional ownership and the possibility of selecting high quality auditors.

H5: there is a positive meaningful relationship between firm size and the possibility of selecting high quality auditors.

\section{Research Methodology}

Data and Sample

Research data for this case study (Jordan) include data for 20 listed firms (service sector) on Amman Stock Exchange for the period 2011-2013.

\section{Proposed Model}

The following empirical model is developed to test the research hypotheses: $\mathrm{y}=\beta 0+\beta 1 \mathrm{BRD} \_S I Z E+\beta 2 \mathrm{BRD} \_I N D+\beta 3 \mathrm{DUAL}+\beta 4 \mathrm{INST} \_\mathrm{OWN}+\beta 5 \mathrm{~F} \_\mathrm{SIZ}+\mu$ Where:

- $\mathrm{Y}$ is a measure for auditor selection and compliance to mandatory disclosure requirements.

- The independent variables are represented by BRD_SIZE, BRD_IND, DUAL and INST_OWN.

- The control variable is represented by F_SIZ.

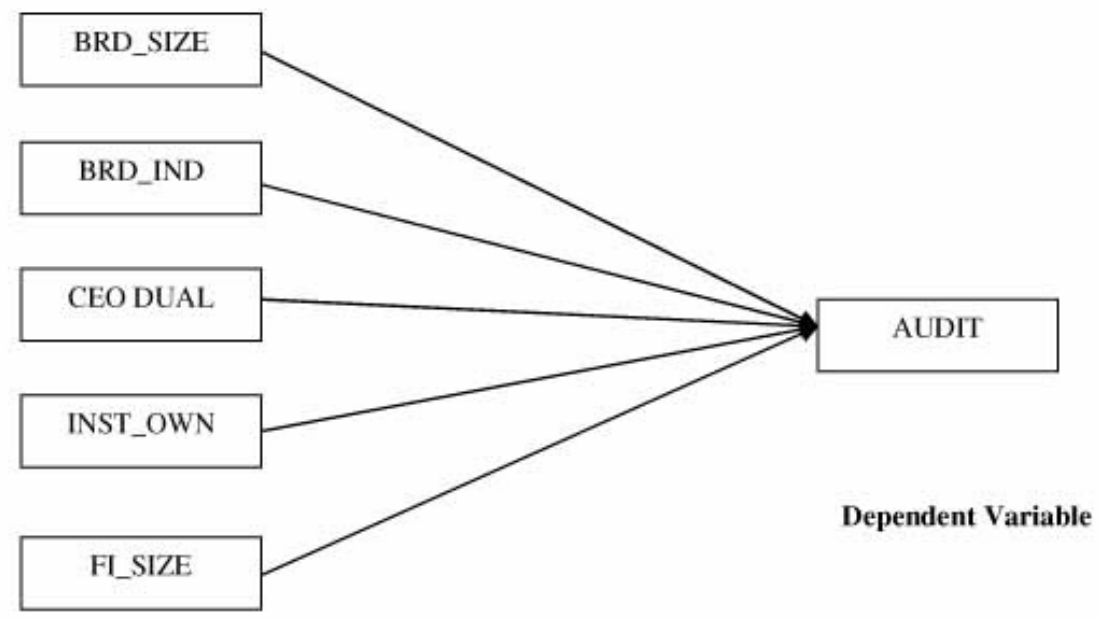

Independent and Control Variables

Figure 1. Research Model 


\section{Data Analysis}

In order to answer the research questions and examine their assumptions descriptive and analytical statistical methods using the statistical package (IBM SPSS), frequencies, percentages, averages, and standard deviations were used. Test of hypotheses will be based on binary logistic regression results.

\section{Descriptive Statistics for the Study Sample}

The study sample consisted of 20 service companies listed in Amman Stock Exchange; the data was collected from the reported financial statements of each company on Amman Stock Exchange site. The following tables (1) and (2) present the descriptive statistics for the dependent variable and the independent variables employed in the study.

Table 1: Descriptive Statistics

\begin{tabular}{|l|r|r|r|r|r|}
\hline & \multicolumn{1}{|c|}{$\mathrm{N}$} & Minimum & Maximum & \multicolumn{1}{c|}{ Mean } & Std. Deviation \\
\hline & Statistic & Statistic & Statistic & \multicolumn{1}{c|}{ Statistic } & \multicolumn{1}{c|}{ Statistic } \\
\hline BSizen & 60 & 4 & 16 & 8.62 & 2.762 \\
POD & 60 & .40 & 1.00 & .8338 & .13432 \\
CEOT & 60 & 1 & 22 & 3.95 & 4.312 \\
NoSHARES & 60 & 500000 & 224699999 & 17953793.47 & 48231120.832 \\
PoOWNER & 60 & .06 & .90 & .4263 & .25784 \\
Valid N (listwise) & 60 & & & & \\
\hline
\end{tabular}

Table 2: Descriptive Statistics
\begin{tabular}{|l|r|r|r|r|r|r|}
\hline & BSize & FA & BIND & CEOD & AUDITSELEC & FirmSize \\
\hline $\mathrm{N} \quad$ Valid & 60 & 60 & 60 & 60 & 60 & 60 \\
\multicolumn{1}{|c|}{ Missing } & 0 & 0 & 0 & 0 & 0 & 0 \\
Mean & .48 & .35 & .48 & .28 & .63 & 1.65 \\
Median & .00 & .00 & .00 & .00 & 1.00 & 1.00 \\
Mode & 0 & 0 & 0 & 0 & 1 & 1 \\
Std. Deviation & .504 & .481 & .504 & .454 & .486 & .860 \\
Variance & .254 & .231 & .254 & .206 & .236 & .740 \\
Minimum & 0 & 0 & 0 & 0 & 0 & 1 \\
Maximum & 1 & 1 & 1 & 1 & 1 & 3 \\
\hline
\end{tabular}

Table (1) and (2) shows that the mean of BRD-SIZE $=.48$, with maximum value of 1 and minimum value of 0 (Binary). While the mean for $B R D-I N D=0.48$, with maximum value of 1 and minimum value of 0 (Binary). The mean for CEO-DUAL $=0.28$, with maximum value of 1 and minimum value of 0 (Binary). And the mean for INST-OWNER = $17,953,793.47$ as number of shares owned by the owners and a mean of $=.43$ as proportion of ownership, with maximum value of 224,699,999 and minimum value of 500,000 for the number of shares and a maximum value of $=.9$ and a minimum value of $=$ .06 for the proportion of ownership. The mean for FIRM-SIZE $=1.65$, with maximum value of 3 and minimum value of 2 ( 3 for large companies and 1 for small companies). The above results seem reasonable and within the normal range. The following section displays the distribution of the study sample by independent variables. 
Journal of Social Sciences (COES\&RJ-JSS), 6(4), pp. 886-901

Table 3: Board Size

\begin{tabular}{|rl|r|r|r|r|}
\hline & & & & \multicolumn{2}{c|}{$\begin{array}{c}\text { Cumulative } \\
\text { Percent }\end{array}$} \\
\hline Valid & Frequency & Percent & Valid Percent & 51.7 \\
& 31 & 51.7 & 51.7 & 100.0 \\
& Total & 49 & 48.3 & 48.3 & \\
\hline
\end{tabular}

Note from Table (3), that the board size of the sample members, of the study conducted, were ranging by $(51.7 \%)$ as large board size and $(48.3 \%)$ as small board size.

Table 4: Board Independence

\begin{tabular}{|rl|r|r|r|r|}
\hline & & & & \multicolumn{2}{c|}{$\begin{array}{c}\text { Cumulative } \\
\text { Percent }\end{array}$} \\
\hline Valid & Frequency & Percent & Valid Percent & 51.7 \\
& 1 & 31 & 51.7 & 51.7 & 100.0 \\
& 29 & 48.3 & 48.3 & \\
\hline
\end{tabular}

Note from Table (4), that $(51.7 \%)$ of the study sample had board independence whereas $(48.3 \%)$ had no board independence.

Table 5: CEO Duality

\begin{tabular}{|ll|r|r|r|r|}
\hline & & & & \multicolumn{2}{c|}{$\begin{array}{c}\text { Cumulative } \\
\text { Percent }\end{array}$} \\
\hline Valid & No Duality & 43 & 71.7 & 71.7 & 71.7 \\
& Duality Exists & 17 & 28.3 & 28.3 & 100.0 \\
& Total & 60 & 100.0 & 100.0 & \\
\hline
\end{tabular}

Note from Table (5), that (71.7\%) of the CEO`s in the companies of the study sample had no duality in their work and (28.3) of them had duality.

Table 6: Auditor Selection

\begin{tabular}{|ll|r|r|r|r|}
\hline & & & & \multicolumn{2}{c|}{$\begin{array}{c}\text { Cumulative } \\
\text { Percent }\end{array}$} \\
\hline Valid & Not Big Four & 22 & 36.7 & 36.7 & 36.7 \\
& Big Four & 38 & 63.3 & 63.3 & 100.0 \\
& Total & 60 & 100.0 & 100.0 & \\
\hline
\end{tabular}

Note from Table (6), that $(36.7 \%)$ of the companies in the study sample didn't use one of the big four auditors, while on the on the other hand $(63.3 \%)$ hired one of the four big auditors. 
The impact of corporate governance .......

Table 7: FirmSize

\begin{tabular}{|ll|r|r|r|r|}
\hline & & & & \multicolumn{2}{c|}{$\begin{array}{c}\text { Cumulative } \\
\text { Prequent }\end{array}$} \\
\hline Valid & Small & 36 & 60.0 & 60.0 & 60.0 \\
& Medium & 9 & 15.0 & 15.0 & 75.0 \\
& Large & 15 & 25.0 & 25.0 & 100.0 \\
& Total & 60 & 100.0 & 100.0 & \\
\hline
\end{tabular}

Note from Table (7), that companies of the sample members, of the study conducted, were ranging by $(60 \%)$ as small companies, (15\%) as medium companies and $(25 \%)$ as large companies.

\section{Table 8: Board Size Statistics}

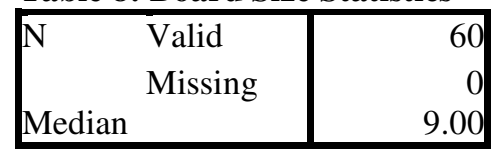

Table 9: Board Size

\begin{tabular}{|ll|r|r|r|r|}
\hline & & & & \multicolumn{2}{|c|}{ Cumulative } \\
& & Frequency & Percent & Valid Percent \\
\hline Valid & 4 & 2 & 3.3 & 3.3 & 3.3 \\
& 5 & 7 & 11.7 & 11.7 & 15.0 \\
& 6 & 6 & 6.7 & 21.7 \\
7 & 10 & 16.7 & 16.7 & 38.3 \\
& & 6 & 10.0 & 10.0 & 48.3 \\
9 & 14 & 23.3 & 23.3 & 71.7 \\
10 & 4 & 6.7 & 6.7 & 78.3 \\
11 & 2 & 3.3 & 3.3 & 81.7 \\
12 & 6 & 10.0 & 10.0 & 91.7 \\
14 & 4 & 6.7 & 6.7 & 98.3 \\
16 & 1 & 1.7 & 1.7 & 100.0 \\
Total & 60 & 100.0 & 100.0 & \\
\hline
\end{tabular}

Table 10: Outside Directors, CEO Tenure and Family Affiliation Statistics

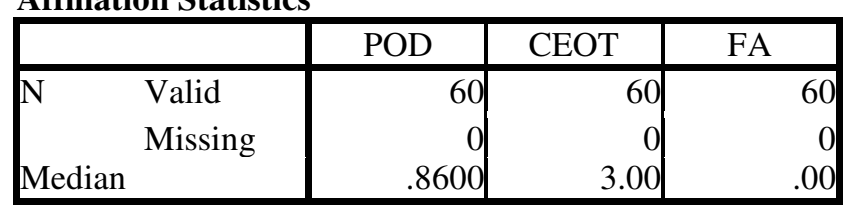


Table 11: Proportion of Outside Directors

\begin{tabular}{|c|c|c|c|c|c|}
\hline & & Frequency & Percent & Valid Percent & $\begin{array}{c}\text { Cumulative } \\
\text { Percent }\end{array}$ \\
\hline Valid & .40 & 2 & 3.3 & 3.3 & 3.3 \\
\hline & .50 & 1 & 1.7 & 1.7 & 5.0 \\
\hline & .57 & 2 & 3.3 & 3.3 & 8.3 \\
\hline & .60 & 2 & 3.3 & 3.3 & 11.7 \\
\hline & .75 & 2 & 3.3 & 3.3 & 15.0 \\
\hline & .78 & 5 & 8.3 & 8.3 & 23.3 \\
\hline & .80 & 4 & 6.7 & 6.7 & 30.0 \\
\hline & .82 & 2 & 3.3 & 3.3 & 33.3 \\
\hline & .83 & 1 & 1.7 & 1.7 & 35.0 \\
\hline & .86 & 11 & 18.3 & 18.3 & 53.3 \\
\hline & .88 & 5 & 8.3 & 8.3 & 61.7 \\
\hline & .89 & 9 & 15.0 & 15.0 & 76.7 \\
\hline & .90 & 1 & 1.7 & 1.7 & 78.3 \\
\hline & .92 & 4 & 6.7 & 6.7 & 85.0 \\
\hline & .93 & 1 & 1.7 & 1.7 & 86.7 \\
\hline & .94 & 1 & 1.7 & 1.7 & 88.3 \\
\hline & 1.00 & 7 & 11.7 & 11.7 & 100.0 \\
\hline & Total & 60 & 100.0 & 100.0 & \\
\hline
\end{tabular}

Table 12: CEO Tenure

\begin{tabular}{|ll|r|r|r|r|}
\hline & & & & \multicolumn{2}{|c|}{$\begin{array}{c}\text { Cumulative } \\
\text { Percent }\end{array}$} \\
\hline Valid & 1 & Frequency & Percent & Valid Percent & 23.3 \\
& 2 & 14 & 23.3 & 23.3 & 43.3 \\
& 12 & 20.0 & 20.0 & 60.0 \\
& 10 & 16.7 & 16.7 & 73.3 \\
& 8 & 13.3 & 13.3 & 83.3 \\
5 & 6 & 10.0 & 10.0 & 91.7 \\
6 & 5 & 8.3 & 8.3 & 95.0 \\
7 & 2 & 3.3 & 3.3 & 96.7 \\
20 & 1 & 1.7 & 1.7 & 98.3 \\
21 & 1 & 1.7 & 1.7 & 100.0 \\
22 & 1 & 1.7 & 1.7 & \\
\hline
\end{tabular}


Table 13: Family Affiliation

\begin{tabular}{|ll|r|r|r|r|}
\hline & & & & \multicolumn{2}{c|}{ Cumulative } \\
& Frequency & Percent & Valid Percent & \multicolumn{2}{c|}{ Percent } \\
\hline Valid & No Family Affiliation & 39 & 65.0 & 65.0 & 65.0 \\
& Family Affiliation Exists & 21 & 35.0 & 35.0 & 100.0 \\
& Total & 60 & 100.0 & 100.0 & \\
\hline
\end{tabular}

\section{Readiness Tests and the Validity of Data for Regression Analysis}

In order to answer the study questions and test their assumptions, the researcher needs to apply different regression analysis. But there are some conditions that should be available in the data in order to be sure of the integrity of that data, and the validity of the regression analysis, which are:

1- $\quad$ The data must be normally distributed (Normal Distribution)

2- The variables should be independent and not interfere with each other (Multicollinearity)

3- Every variable must be correlated to itself more than its correlation with other variables (Correlation)

In the absence of these conditions, the researcher should not use regression analysis; he should use (Non-Parametric Tests).

\section{Test of Normality}

To test whether the data were normally distributed, the researcher used Skewness-Kurtosis test. Table (14) and (15) shows that most of the skewness values and kurtosis values are between \pm 2 which indicates that most of the study variables are distributed normally (Hair et al, 2006).

Table 14: Test of Normality using Skewness-Kurtosis Test

\begin{tabular}{|c|c|c|c|c|c|c|}
\hline & BSize & FA & BIND & CEOD & AUDITSELEC & FirmSize \\
\hline $\mathrm{N}$ Valid & 60 & 60 & 60 & 60 & 60 & 60 \\
\hline Skewness & .068 & .645 & .068 & .986 & $-.568-$ & .755 \\
\hline Std. Error of Skewness & .309 & .309 & .309 & .309 & .309 & .309 \\
\hline Kurtosis & $-2.065-$ & $-1.640-$ & -2.065 & $-1.063-$ & $-1.737-$ & -1.226 \\
\hline Std. Error of Kurtosis & .608 & .608 & .608 & .608 & .608 & .608 \\
\hline
\end{tabular}

\subsubsection{Pearson Correlation}

Pearson correlation was applied to test if every variable is correlated to itself more than its correlation with other variables. This test enhances the degree of certainty in variables independency and that they don't interfere with each other, thus, its suitability and 
readiness for regression analysis. Tables (15) and (16) show that every variable is correlated to itself more than its correlation with other variables in the study.

Table 15: Pearson Correlation Analysis

\begin{tabular}{|c|c|c|c|c|c|c|}
\hline & & BSizen & POD & CEOT & NoSHARES & PoOWNER \\
\hline \multirow[t]{3}{*}{ BSizen } & Pearson Correlation & 1 & $.374^{* * *}$ & $.401^{* * *}$ & $-.097-$ & .038 \\
\hline & Sig. (2-tailed) & & .003 & .001 & .462 & .773 \\
\hline & $\mathrm{N}$ & 60 & 60 & 60 & 60 & 60 \\
\hline \multirow[t]{3}{*}{ POD } & Pearson Correlation & $.374^{* * x}$ & 1 & .066 & $.314^{*}$ & $.327^{\prime \prime}$ \\
\hline & Sig. (2-tailed) & .003 & & .617 & .015 & .011 \\
\hline & $\mathrm{N}$ & 60 & 60 & 60 & 60 & 60 \\
\hline \multirow[t]{3}{*}{ CEOT } & Pearson Correlation & $.401^{* * *}$ & .066 & 1 & -.079 & $-.117-$ \\
\hline & Sig. (2-tailed) & .001 & .617 & & .547 & .375 \\
\hline & $\mathrm{N}$ & 60 & 60 & 60 & 60 & 60 \\
\hline \multirow[t]{3}{*}{ NoSHARES } & Pearson Correlation & $-.097-$ & $.314^{*}$ & -.079 & 1 & $.464^{* * * 4}$ \\
\hline & Sig. (2-tailed) & .462 & .015 & .547 & & .000 \\
\hline & $\mathrm{N}$ & 60 & 60 & 60 & 60 & 60 \\
\hline \multirow[t]{3}{*}{ PoOWNER } & Pearson Correlation & .038 & $.327^{*}$ & $-.117-$ & $.464^{* *+2}$ & 1 \\
\hline & Sig. (2-tailed) & .773 & .011 & .375 & .000 & \\
\hline & $\mathrm{N}$ & 60 & 60 & 60 & 60 & 60 \\
\hline
\end{tabular}

**. Correlation is significant at the 0.01 level (2-tailed).

*. Correlation is significant at the 0.05 level (2-tailed).

Table 16: Pearson Correlation Analysis

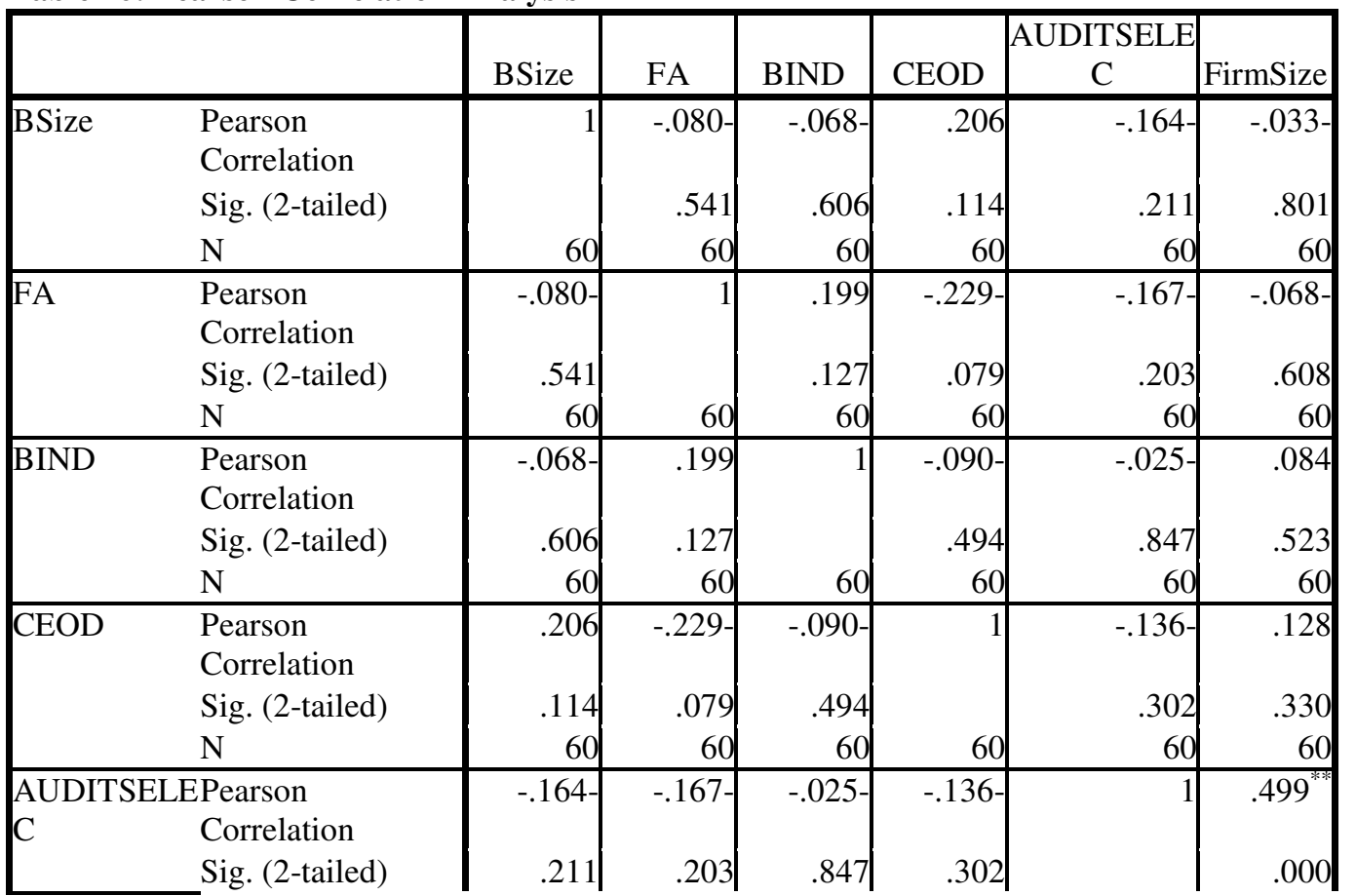


The impact of corporate governance ......

\begin{tabular}{|c|c|c|c|c|c|c|c|}
\hline & $\mathrm{N}$ & 60 & 60 & 60 & 60 & 60 & 60 \\
\hline \multirow[t]{3}{*}{ FirmSize } & $\begin{array}{l}\text { Pearson } \\
\text { Correlation }\end{array}$ & $-.033-$ & $-.068-$ & .084 & .128 & $.499^{*}$ & \\
\hline & Sig. (2-tailed) & 801 & .608 & .523 & .330 & .000 & \\
\hline & $\mathrm{N}$ & 60 & 60 & 60 & 60 & 60 & 60 \\
\hline
\end{tabular}

**. Correlation is significant at the 0.01 level (2-tailed).

BSize: Board Size

POD: Proportion of Outside Directors

CEOT: CEO Tenure

NoSHARES: Number of shares

PoOwners: Proportion of Ownership

FA: Family Affiliation

BIND: Board Independence

CEOD: CEO Duality

AUDITSELEC: Auditor Selection

FirmSize: Firm Size

According to table (15) and (16) there is a relatively moderate correlation between BSize \& CEOT (0.401) and POD \& BSize (0.374) which is significant at $1 \%$ level. Among the independent variables, FIRMSIZE shows the highest correlation with the dependent variable (Auditor Selection), with a correlation coefficient of 0.499. Depending on the results of the validity and readiness of the data, we can now use regression analysis tests to answer the study questions and test the hypotheses.

\section{Binary Logistic Regression Model \\ Test of the Study Hypotheses}

H1: there is a positive meaningful relationship between board size and the possibility of selecting high quality auditors.

$\mathrm{H} 2$ : there is a positive meaningful relationship between board independence and the possibility of selecting high quality auditors.

H3: there is a positive meaningful relationship between duality of the CEO and chairman roles and the possibility of selecting high quality auditors.

H4: there is a positive meaningful relationship between institutional ownership and the possibility of selecting high quality auditors.

H5: there is a positive meaningful relationship between firm size and the possibility of selecting high quality auditors.

Table (17) indicates that the regression model is in general significant at 0.01 level.

Table 17: Hosmer and Lemeshow Test

\begin{tabular}{|l|r|r|r|}
\hline Step & Chi-square & df & \multicolumn{1}{c|}{ Sig. } \\
\hline 1 & 24.699 & & 8
\end{tabular}


Table 18: Classification Table ${ }^{\mathrm{a}, \mathrm{b}}$

\begin{tabular}{|c|c|c|c|c|}
\hline & \multirow[b]{3}{*}{ Observed } & \multicolumn{3}{|c|}{ Predicted } \\
\hline & & \multicolumn{2}{|c|}{ AUDITSELEC } & \multirow{2}{*}{$\begin{array}{c}\text { Percentage } \\
\text { Correct }\end{array}$} \\
\hline & & Not Big Four & Big Four & \\
\hline Step 0 & $\begin{array}{ll}\text { AUDITSELEC } & \text { Not Big Four } \\
& \text { Big Four }\end{array}$ & $\begin{array}{l}0 \\
0\end{array}$ & $\begin{array}{l}22 \\
38\end{array}$ & $\begin{array}{r}.0 \\
100.0 \\
63.2\end{array}$ \\
\hline
\end{tabular}

a. Constant is included in the model.

b. The cut value is .500

Table (18) shows that 22 company of the study sample didn't hire one of the big four auditors, whereas 38 company hired them with an overall percentage of $(63.3 \%)$.

Table 19: Model Summary

\begin{tabular}{|l|r|r|r|}
\hline Step & -2 Log likelihood & $\begin{array}{c}\text { Cox \& Snell R } \\
\text { Square }\end{array}$ & $\begin{array}{c}\text { Nagelkerke R } \\
\text { Square }\end{array}$ \\
\hline 1 & $54.769^{\mathrm{a}}$ & .331 & .452 \\
\hline
\end{tabular}

a. Estimation terminated at iteration number 6 because parameter estimates changed by less than .001 .

The regression results reported in table (19) show a relatively moderate value for the R2 of 0.452 .

Table 20: Regression Coefficients Results

\begin{tabular}{|rl|r|r|r|r|r|}
\hline & & \multicolumn{1}{c|}{ B } & \multicolumn{1}{c|}{ S.E. } & \multicolumn{1}{c|}{ Wald } & df & \multicolumn{1}{c|}{ Sig. } \\
\hline Step $1^{\mathrm{a}}$ & BSize & $-.431-$ & .692 & .389 & 1 & .533 \\
& BIND & -.743 & .764 & .947 & 1 & .331 \\
& CEOD & -1.440 & .830 & 3.008 & 1 & .083 \\
FirmSize & 2.257 & .823 & 7.522 & 1 & .006 \\
NoSHARES & .000 & .000 & .004 & 1 & .950 \\
PoOWNER & .943 & 1.537 & .377 & 1 & .539 \\
Constant & -2.042 & 1.213 & 2.833 & 1 & .092 \\
\hline
\end{tabular}

a. Variable(s) entered on step 1: BSize, BIND, CEOD, FirmSize, NoSHARES, PoOWNER.

According to regression results in table (20), only Firm Size is shown to be positively \& significantly associated with Auditor Selection with a regression coefficient of .006, which is also statistically significant at 0.05 level. The other regression coefficients for the remaining independent variables failed to be statistically significant.

\section{Research Results}

The results of the analysis show that:

Board Size (BRD-Size) does not have a significant effect on Auditor Selection. Selection.

Board Independence (BIND) does not have a significant effect on Auditor

CEO Duality (CEOD) does not have a significant effect on Auditor Selection. 
- Institutional Ownership (INST-OWNER) does not have a significant effect on Auditor Selection.

- $\quad$ Firm Size (FirmSize) has a significant effect on Auditor Selection.

\section{Discussion and Conclusions}

The results of this study show that only the Firm Size variable has a significant effect on Auditor Selection, although in the researchers opinion the other variables are very important and do affect Auditor Selection due to their importance. This study has proven the opposite were the data analyzed did not show this relationship for the chosen sample maybe due to the small sample that was undertaken. Also, the current research recommends:

- Results from testing the hypotheses reflect that Firm Size has a significant effect on Auditor Selection. And that the other variables don't have a significant effect on the Auditor Selection. Thus, the management of companies needs better understanding of critical factors affecting the Auditor Selection and how to measure them.

- Additional Future research can be done on other sectors for additional benefits.

- Additional Future research can be done on other variables and their effect on Auditor Selection.

\section{References}

Armstrong, C., Guay, W. and Weber, J. (2010), "The Role of Information and Financial Reporting in Corporate Governance and Debt Contracting" Working Paper, University of Pennsylvania and Massachusetts Institute of Technology (March 14).

Asku, M., Onder, T. and Saatcioglu, K. (2007), "Auditor Selection, Client Firm Characteristics, and Corporate Governance: Evidence from an Emerging Market”.

Berle, A. A. and Means, G. C. (1932), "The Modern Corporation and Private Property", Macmillan, NY.

Brickley, A. and Zimmerman, L. (2010), “Corporate Governance Myths: Comments On Armstrong, Guay, and Weber" available at: http://SSRN.COM/abstract=1681030 (accessed August 4, 2012).

Broye, G. and L. Weill (2008), "Does Leverage Influence Auditor Choice? A Cross-Country Analysis”, Applied Financial Economics, Vol. 18, No. 9, pp 715-731.

Gao, L. and Kling, G. (2012), "The Impact Of Corporate Governance And External Audit On Compliance To Mandatory Disclosure Requirements In China" Journal of International Accounting, Auditing and Taxation, Vol. 21, pp. 44-59.

Hossain, M., Lim, C. and Tan, P., (2010),"Corporate Governance, Legal Environment And Auditor Choice In Emerging Markets" Review of Pacific Basin Financial Markets and Policies, Vol. 13, No. 1, pp. 91-126.

Jennings, R. and Marques, A. (2007), "The Impact of Corporate Governance on The Disclosure of Manager-Adjusted Non Gaap Earnings". 
Jensen, M.C. and W.H. Meckling (1976), "Theory of the Firm: Managerial Behaviour, Agency Costs and Ownership Structure", Journal of Financial Economics, Vol. 3, No. 4, pp. 305-360.

Khan, H. (2011), "A Literature Review of Corporate Governance" International Conference on E-business, Management and Economics, IPEDR Vol. 25, in Singapore.

Larcker, D. F., S. A. Richardson, and I. Tuna (2007), "Corporate Governance, Accounting Outcomes, and Organizational Performance" The Accounting Review, Vol. 82, No. 4, pp 963-1008.

Lin, Z. J. and Liu, M. (2009), “The Impact of Corporate Governance on Auditor Choice: Evidence from China", Journal of International Accounting, Auditing and Taxation, pp. 44-59.

Lin, Z. J. and Liu, M. (2010), "The determinants of Auditor Switch from the Perspective of Corporate Governance in China", Advances in Accounting, Incorporating Advances in International Accounting, Vol. 26, pp. 117-127.

Mahdavi, G., Maharlouie, M., Ebrahimi, F. AND Sarikhani, M. (2011), "The Impact of Corporate Governance on Auditor Choice" International Research Journal Of Finance And Economics, Vol. 11, pp. 129-139.

Ming, L. (2007), “Corporate Governance, Auditor Choice and Auditor Switch”.

Muhamad, R., Lumpur, K., Shahimi, S., Yahya, Y. and Mahzan,N. (2009), "Disclosure Quality On Governance Issues In Annual Reports Of Malaysia”. 